\title{
THE OSCE-EXPERIMENT AT MEDUNSA
}

\author{
PROF J G P VAN NIEKERK
}

B Cur M Cur (General Intensive Nursing) M Cur (Nursing administration) General Nurse, Midwife, Psychiatric Nurse, Tutor, Nurse Administrator, Community Nurse, Intensive Care Nurse MRS S A LOMBARD

B Cur (I et A) General Nurse, Midwife, Tutor, Nurse Administrator, Community Nurse

\section{OPSOMMING}

Die Departement Verpleegkunde van MEDUNSA het 'n nuwe metode vir kliniese evaluering op die proef gestel in die evaluering van eerstejaar B.Cur-studente. Die Objektiewe Gestruktureerde Kliniese Eksamen (OGKE) is minder subjektief as die gebruiklike metodes en die areas wat geëvalueer gaan word, word vooraf noukeurig beplan.

Die eksamen word afgeneem in 'n aantal voorafopgestelde stasies en studente word evalueer aan die hand van kontrolelyste vir elke stasie. Die eksamen sluit prosedures wat deur die eksaminator waargeneem word in, asook prosedures waar die student die resultaat neerskryf of 'n vraelys daaroor voltooi, en mondelinge ondervraging.

Die persone betrokke by die OGKE-eksperiment aan MEDUNSA het gevind dat dit 'n uitstekende evalueringsmetode is wat in die vervolg gebruik gaan word. Die metode word aanbeveel vir alle opleidingskole wat hul standaard van kliniese evaluering wil verbeter.

\section{INTRODUCTION}

The newly-established Department of Nursing Science at MEDUNSA had provisionally decided to use the conventional approach to the clinical examination of the ten pre-registration students on the B.Cur. course. During October 1981 Professor R M Harden, Professor in Medical Education, University of Dundee, Scotland, paid a lecture visit to MEDUNSA. In one lecture Professor Harden described a method used for examining clinical skills of medical students in the University of Dundee. It is called the Objective Structured Clinical Examination (OSCE). It consists of an examination in which a wide range of skills are evaluated through practical, written and oral methods of assessment. OSCE can thus be described as :... an approach to the assessment of clinical competence which attempts to improve the reliability and validity of traditional methods, while at the same time providing a practical technique appropriate for use with large numbers of students... (1, p. 145)
The personnel of the Department of Nursing Science at MEDUNSA decided to apply this method in the clinical examination of the students in nursing science in their first year of pre-registration training. Thus it became the first department in the university to apply this method of clinical examination. It will be applied in all the departments of MEDUNSA in future.

\section{WHAT IS OSCE?}

OSCE . . is a method of assessing a student's clinical competence which is objective rather than subjective, and in which the areas tested are carefully planned by the examiners. (2, p.118) These important characteristics of the method are often sadly lacking in the conventional methods of assessment in nursing. Usually two people assess a student on a practical procedure followed by an oral assessment. In OSCE . . the clinical competence to be tested is broken down into its various components . . Each component is assessed in turn and is the objective of one of the stations in the examination. The student during the examination, rotates round a number of stations, . . . spending a specified time at each station. On a signal (usually a bell) the student moves on to the next station. The time allowed is the same for all the stations and the stations must be designed with this in mind (2. p.118).

Originally there were only two types of stations, namely procedure stations, and question stations, where a procedure, such as an abdominal examination is performed at the procedure station and a questionnaire regarding the same procedure is completed at the next station. Over the years this has developed to the extent that Professor Harden presently identifies nine types of stations.

In the application of OSCE to nursing, five types of stations were identified, namely stations where:

- procedures were performed with an examiner in attendance.

The examiner immediately recorded the correctness of the procedure being performed on the checklist. A procedure such as taking blood-pressure constitutes this type of station; 
- procedures were performed without an examiner in attendance. The students were evaluated by the correctness of the results of their performance of the procedure, recorded by themselves while performing the procedure. Urinalysis constituted this type of station;

- procedures performed according to the original procedure and question stations pattern. There was no examiner in attendance. A procedure like taking and recording a patient's history constituted this type of station;

- oral examinations on specific topics were conducted by an examiner. The care of a patient receiving a blood transfusion constituted this category:

- questionnaires on selected topics had to be completed by the students. The explanation of a few frequently used diagnoses constituted this type of station.

A checklist was compiled for every procedure, independent of the type of station. At stations where examiners were present, the checklists were completed immediately and the students scored while they were busy performing the procedures or doing the oral examination. The checklists at the stations not manned by examiners were either questionnairs completed by the students, or checklists regarding what they had written on a form. These were scored by the examiners directly after the examination. Marks were allocated for each procedure on the checklist and the total marks were easily calculated by determining the marks for each checklist, adding these for all checklists and calculating the percentage as a final mark for every student

In Dundee, all students who qualify for supplementary examinations after the OSCE are given an oral examination within a few hours after OSCE, because the marks can be calculated immediately and results made available after the examination. Luckily this was not necessary at MEDUNSA because all the students passed the examination. But it could be done in this way when necessary and while all the examiners are still present to conduct the oral examination together.

\section{APPLICATION OF OSCE}

The procedures and methods decided on for the clinical examination of first-year nursing students at MEDUNSA are shown in Table 1.
The stations were set up in two large interleading demonstration rooms. The students were briefed to rotate from station to station as soon as the bell rang and after washing their hands in between. Two minutes were allowed between stations for washing hands to stress the fact that a nurse never moves from one patient to the next without washing her hands.

Different types of demonstration dolls were used as patients as far as possible. Where live people had to be used at the stations such as for taking a patient's history, or a blood-pressure, volunteers from the post-registration student groups acted as simulated patients. They were briefed on their roles as patients.

A very important factor in this method of evaluation was the attitudes of the examiners. The examiners used in this experiment did a marvellous job. The staff members of the Department of Nursing Science, nurses from the Ga-Rankuwa Hospital and College of Nursing who were interested in the project and a doctor attached to the Department of Pharmacology at MEDUNSA were used as examiners. All were properly briefed and allocated, as far as possible, to stations in which they were interested. Each

\section{TABLE 1 OSCE FOR FIRST YEAR STUDENT NURSES - PROCEDURES AND METHODS}

\begin{tabular}{|c|c|}
\hline PROCEDURE & METHOD \\
\hline $\begin{array}{l}\text { 1. Taking of blood-pressure } \\
\text { 2. Blood transfusion } \\
\text { 3. Oxygen therapy } \\
\text { 4. Taking of temperature, pulse } \\
\text { and respiration } \\
\text { 5. Care of back and pressure parts } \\
\text { 6. Prevention of cross infection } \\
\text { 7. Bandaging of knee joint } \\
\text { 8. Checking of intravenous } \\
\text { therapy } \\
\text { 9. Administering of medicine } \\
\text { 10. Urinalysis } \\
\text { 11. Report writing } \\
\text { 12. Taking of patient's history } \\
\text { 13. Administering of naso-gastric feed } \\
\text { 14. Explanation of diagnosis }\end{array}$ & $\begin{array}{l}\text { Observed and scored by examiner } \\
\text { Oral examination by examiner } \\
\text { Observed and scored by examiner } \\
\text { Observed and scored by examiner } \\
\text { Observed and scored by examiner } \\
\text { Oral examination by examiner } \\
\text { Observed and scored by examiner } \\
\text { Observed and scored by examiner } \\
\text { Observed and scored by examiner } \\
\text { Results written down on checklist } \\
\text { by student } \\
\text { Report on patient described in briefing } \\
\text { written on official form used in hospital } \\
\text { and marked on checklist afterwards. } \\
\text { History taken at one station and ques- } \\
\text { tionnaire on it completed at next station. } \\
\text { Observed and scored by examiner } \\
\text { Questionnaire completed by student. }\end{array}$ \\
\hline
\end{tabular}


was provided with a checklist for every student.

The following is an example of what happened at a station.

For this specific procedure the student went to a station marked Intravenous therapy where intravenous therapy was administered to a demonstration doll. The doll was identified in the standard method in use in the training hospital, there was an official prescription sheet, completed in the correct way. The required intravenous therapy had been prescribed by a real medical practitioner. The instruction card read: Check the intravenous therapy and while doing it explain to the examiner what you are doing and why you are doing it.

The examiner indicated the score on the checklist while the student explained her actions to him.

The checklist for this specific station is shown in Table 2

\section{RESULTS OBTAINED WITH OSCE IN THE EXPERIMENT}

The examination went very well. There were only two problems, namely:

- one student who, without realising it, skipped one station and

\section{TABLE 2 EXAMPLE OF A CHECKLIST FOR AN OSCE STATION}

\section{MEDUNSA \\ NURSING SCIENCE DEPARTMENT}

OBJECTIVE STRUCTURED CLINICAL EXAMINATION (OSCE) CHECKLIST FOR CHECKING OF INTRAVENOUS THERAPY (Copyright reserved)

NAME:

STUDENT REGISTRATION NUMBER:

DATE:

TIME ALLOWED FOR PROCEDURE:

SIGNATURE AND DESIGNATION OF ASSESSOR: .

MARKS

\section{Approach}

1.1 Does she perform the procedure in the right sequence?

\section{Technique}

2.1 Does she identify the patient as compared with the prescription sheet?

2.2 Does she check that the fluid in the vaculiter attached to the patient is the same as the prescribed fluid?

2.3 Does she check the prescription and whether the vaculiter has been labelled according to the prescription?

2.4 Does she check and control the labelling of the vaculiter according to the time it must run in?

2.5 Does she check whether the intravenous infusion set is of the correct type for the correct type of fluid?

2.6 Does she check whether the intravenous infusion lines has not been blocked in any way?

2.7 Does she check whether there is air in the line?

2.8 Does she control the tempo at 30 drops per minute?

2.9 Does she check whether the infusion is running into the tissues by observing the area where it pierces the skin?

ASSESSOR: Instruct the nurse to go and wash her hands please.

\begin{tabular}{|c|l|}
\hline $\begin{array}{l}\text { CHECKLIST } \\
\text { RATING }\end{array}$ & $\begin{array}{l}\text { STUDENT } \\
\text { RATING }\end{array}$ \\
\hline 10 & \\
\hline
\end{tabular}

thus did not get any marks for it, and

- at the urinalysis station, where an Esbach's albumin test had to be set up, the procedure was found to be too long for the five-minute period allowed for performing it.

In the case of the procedure that was too long, the second part of the procedure was not marked and the marks were adapted in order not to penalise the students for a mistake in the planning and organisation.

A summary of the results of the examination, compared to the achievement of the students throughout the year, is given in Table 3. The students' marks are ranked from the highest to the lowest scores for the examination and the procedures in the order of highest to lowest average percentage achieved in the examination.

At this stage only a few conclusions will be drawn from the results:

- There are a few procedures in which the students did not do well, especially in comparison with those who are the high scorers. In this, one of the advantages of the OSCE-approach is shown, namely that the lecturers can identify shortcomings in their teaching.

It is remarkable that there is a difference of ten percent between the average obtained for the first procedures as compared to the last six procedures. This requires more attention to be paid in teaching to the last six procedures. With very few exceptions the individual marks of the students decreased in relation to the decrease in average percentage for the procedures - another indication that there might be a teaching problem.

- The fact that the average percentage for the group of students for both the methods of evaluation was the same, is quite interesting. There is however a smaller difference between the percentages obtained in the traditional method of clinical examination and the year marks of the students than between the results of the OSCE-method and the year mark. Two factors could have contributed to this phenomenon: 
TABLE 3 ACHIEVEMENT OF TEN STUDENTS IN FOURTEEN PROCEDURES, RANKED ACCORDING TO DECREASING AVERAGE PERCENTAGE OBTAINED IN EVERY PROCEDURE

\begin{tabular}{|c|c|c|c|c|c|c|c|c|c|c|c|c|c|}
\hline \multirow[t]{2}{*}{ Procedures } & \multirow{2}{*}{$\begin{array}{l}\text { Marks } \\
\text { Alloca- } \\
\text { ted to } \\
\text { proce- } \\
\text { dure }\end{array}$} & \multicolumn{10}{|c|}{ Scores of Students $\mathrm{A}-\mathrm{J}$} & \multirow[t]{2}{*}{$\begin{array}{l}\text { Average } \\
\% \text { for } \\
\text { procedure }\end{array}$} & \multirow[t]{2}{*}{$\begin{array}{l}\text { Type } \\
\text { of } \\
\text { procedure }\end{array}$} \\
\hline & & A & B & C & D & $\mathrm{E}$ & $\mathrm{F}$ & $\mathrm{G}$ & $\mathrm{H}$ & I & $\mathbf{J}$ & & \\
\hline $\begin{array}{l}\text { Prevention of } \\
\text { cross infection }\end{array}$ & 10 & 9 & 8 & 9 & 9 & 10 & 8 & 10 & 8 & 9 & 9 & 89 & Oral \\
\hline $\begin{array}{l}\text { Taking of blood- } \\
\text { pressure }\end{array}$ & 10 & 9 & 8 & 7 & 9 & 9 & 9 & 6 & 8 & 7 & 8 & 80 & Practical \\
\hline $\begin{array}{l}\text { Care of back and } \\
\text { pressure parts }\end{array}$ & 20 & 17 & 19 & 16 & 15 & 17 & 11 & 17 & 15 & 15 & 16 & 79 & Practical \\
\hline $\begin{array}{l}\text { Administering of } \\
\text { oxygen therapy }\end{array}$ & 10 & 9 & 8 & 6 & 9 & 9 & 6 & 6 & 9 & 7 & 7 & 76 & Practical \\
\hline History taking & 15 & 7 & 14 & 14 & 14 & 14 & 11 & 7 & 12 & 9 & 8 & 73 & Prac-Quest. \\
\hline $\begin{array}{l}\text { Taking of tempe- } \\
\text { rature, pulse } \\
\text { and respiration }\end{array}$ & 15 & 13 & 12 & 11 & 9 & 13 & 11 & 13 & 8 & 10 & 9 & 73 & Practical \\
\hline $\begin{array}{l}\text { Observations at } \\
\text { blood transfusion }\end{array}$ & 10 & 8 & 8 & 8 & 8,5 & 6 & 8,5 & 7,5 & 7 & 5 & 6 & 73 & Oral \\
\hline $\begin{array}{l}\text { Checking of Intra- } \\
\text { venous Therapy }\end{array}$ & 10 & 8 & 7 & 7 & 7 & 7 & 7 & 8 & 7 & 6 & 7 & 71 & Oral \\
\hline Report writing & 10 & 5 & 5 & 8 & 9 & $0^{*}$ & 9 & 6 & 7 & 6 & 6 & 61 & Written \\
\hline $\begin{array}{l}\text { Administering of } \\
\text { medicine }\end{array}$ & 15 & 11 & 6 & 10 & 10 & 10 & 9 & 9 & 12 & 7 & 7 & 61 & Practical \\
\hline $\begin{array}{l}\text { Administering of } \\
\text { naso-gastric } \\
\text { feeding }\end{array}$ & 15 & 11 & 7 & 3 & 6 & 7 & 6 & 5 & 6 & 6 & 3 & 60 & Practical \\
\hline $\begin{array}{l}\text { Bandaging a } \\
\text { patient's knee }\end{array}$ & 10 & 6 & 7 & 6 & 4 & 5 & 7 & 7 & 5 & 6 & 6 & 59 & Practical \\
\hline Urinalysis & 10 & 5 & 6 & 6 & 4 & 4 & 6 & 6 & 6 & 7 & 6 & 56 & Practical \\
\hline $\begin{array}{l}\text { Explanation of } \\
\text { diagnosis }\end{array}$ & 10 & 3 & 6 & 9 & 6 & 6 & 7 & 8 & 3 & 1 & 3 & 52 & Written \\
\hline$\overline{\text { TOTAL }}$ & 170 & 122 & 121 & 120 & 119.5 & 117 & 115,5 & 115,5 & 113 & 101 & 101 & 114,5 & \\
\hline$\%$ & & 72 & 71 & 71 & 70 & 69 & 68 & 68 & 66 & 59 & 59 & 67 & \\
\hline Year mark $(\%)$ & & 67 & 58 & 63 & 65 & 73 & 72 & 79 & 63 & 50 & 60 & 65 & \\
\hline $\begin{array}{l}\text { Traditional } \\
\text { Practical } \\
\text { Examination (\%) }\end{array}$ & & 72 & 65 & 60 & 61 & 65 & 73 & 78 & 70 & 55 & 68 & 67 & \\
\hline
\end{tabular}

- Student did not perform procedure

- The practical evaluation. This mark was included in the year mark.

- The subjectivity of the examiners. The lecturers know the students very well. Without a checklist, subjectivity may cause the lecturer undertaking evaluation based on one procedure only to allocate marks according to expectations.

As the same average percentage was obtained in both approaches, this could indicate that students can perform at a specific level. The question however remains whether the breakdown of marks per student is a true reflection of the student's ability.
- The OSCE-method gave percentages between 72 and 59 , that is a range of 13 percent. In the traditional method the range was 23 percent, between 78 and 55 percent. In the traditional approach the student performing best in the theoretical part, obtained the highest marks, and the one performing the weakest in the theoretical part, obtained the lowest mark. This is not a true reflection of the student's practical ability, as shown in their continuous evaluation.

\section{CONCLUSIONS AFTER USING THE OSCE-METHOD}

The method was used experimentally because it is believed that the time is ripe for a change in the evaluation of students in the clinical field. We believe that this is a very useful method of evaluation requiring further experimentation and research. For pre-registration students at MEDUNSA it will definitely be the method of clinical evaluation in the foreseeable future. It is not easier or less time-consuming than the traditional method. As a matter of fact, it could be the direct opposite. Time and effort saved in the actual performance of the evaluation, is spent in preparing for it Compiling checklists, questionnaires, instruction cards, orientation of simulated patients, examiners and students, and preparing the examination area with all the 
equipment, stationery and numerous other requirements, takes days of much thinking, planning and self-evaluation.

One advantage of the OSCEmethod is that after all the necessary documents have been drawn up and the stations have been planned properly, the results of this work can be put into a clinical evaluation bank for future use in the evaluation of students at the same level of training. Procedures could be used repeatedly, with new ones added every time. In this way quite a number of procedures will be readily available to be utilised for different categories of students without the effort expended on arranging the first OSCE.

No list of advantages and disadvantages is supplied in this article. To date only the one experiment described herein has been conducted and much more work is needed in this field. For the personnel and students of the Department of Nursing Science at MEDUNSA the experiment was rewarding and the next round of clinical evaluations of both the first and second year B Cur students is being planned already.

The authors want to recommend the use of the OSCE-method of clinical evaluation to all training schools interested in improving their standard of clinical evaluation.

\section{REFERENCES \\ 1. Harden, R.M. Self assessment. Medical Teacher. Vol 2 No 3: 145 - 148. May/June 1980 . \\ 2. Harden, R.M. Assessment in Medical Education - A Work Manual. Blocmfontein. 6-9 October 1981. (Not published)}

\section{VOLTOOIDE NAVORSING COMPLETED RESEARCH}

\section{DIE HANTERING VAN SWAARBESEERDE PASIËNTE VANAF DIE ONGELUKSTONEEL TOT BY DIE ONGEVALLE-AFDELING}

\section{Anna Dorothea Helena Botha (gebore Geldenhuys)}

\author{
Departement Verpleegkunde, Universiteit van Pre- \\ toria \\ Magister Curationis (Gevorderde Algemene Ver- \\ pleegkunde)
}

\section{SAMEVATTING}

'n Gevolg van die moderne nywerheids- en tegnologiese eeu is dat pasiënte met veelvuldige trouma vinnig toeneem. Dit is bewys dat komplikasies minder en die mortaliteit laer is by pasiënte wat voor opname in die ongevalle-afdeling hoë kwaliteit sorg kry. In SuidAfrika is daar ruimte vir verbetering in die sorg wat swaarbeseerdes gedurende die vervoerproses kry.

Ten einde aan te toon hoe kompleks die hantering van 'n swaarbeseerde kan wees, word 'n aantal oorsake van ongelukke, tipes beserings en moontlike komplikasies daarvan bespreek en word dit statisties toegelig. Die psigologiese effek van trouma op die mens word ook bespreek.

Daar is 'n groot ooreenkoms tussen die intensiewesorgsituasie en die situasie tydens vervoer van 'n pasiënt met trouma. In albei gevalle -

- bestaan basiese menslike behoeftes asook behoeftes wat gespesialiseerde, kundige sorg benodig;

- heers 'n atmosfeer met spanning gelaai omdat kritieke siek pasiënte versorg word;

- is die bepaling van prioriteite lewensnoodsaaklik en

- is noukeurige dokumentasie belangrik.

Die intensiewesorgverpleegkundige se beroepsvoorbereiding maak van haar ' $n$ kundige en selfstandige professionele persoon. Sy is daarom die ideale persoon om die swaarbeseerde pasiënt in die prehospitaalfase te versorg. Sy is toegerus om op wetenskaplike wyse die pasiënt se behoeftes te bepaal, bepland daarin te voorsien en haar optrede deurlopend te evalueer en te dokumenteer.

Die navorser is daarvan oortuig dat die intensiewesorgverpleegkundige in die behoefte van hoë kwaliteit sorg tydens die vervoer van swaarbeseerdes kan voorsien. Sy beveel ooreenkomstig aan, asook dat noodambulansdienste uit ongevalle-afdelings funksioneer en 'n troumaverpleegkundekursus in Suid-Afrika ingestel word.

\section{THE UTILIZATION OF THE REGISTERED GENERAL NURSE IN THE REPUBLIC OF SOUTH AFRICA Silvia Angelina Pera}

\author{
Department of Nursing Science, University of Pre- \\ toria \\ Magister Curationis (Nursing Administration)
}

\section{SUMMARY}

An attempt has been made in this study to illustrate the comprehensive role of the registered general nurse in the Republic of South Africa.

It is evident that this category of nurse is in a key position to provide professional nursing and health care to the citizens of this country. Functioning as an independent decision-maker in the doctor-nurse team, the nurse as a professional partner is the person who can humanise the complex scientific service provided.

The study reveals that the registered general nurse with her professional knowledge and skill is functioning as the extended arm of medicine. The multiplicity of functions she fulfills requires constant and on-going nursing education. The unique and dynamic service provided to the community she serves is proof of her professional commitment.

The study reveals, however, that if the needs of society are to be met, additional enabling legislation and constant on-going in-service education should be provided to permit her to function effectively. 